\title{
The Marquis de Sade and induced abortion
}

\author{
A D Farr NE Scotland Blood Transfusion Service, Aberdeen
}

\begin{abstract}
Author's abstract
In 1795 the Marquis de Sade published his La Philosophie dans le boudoir, in which he proposed the use of induced abortion for social reasons and as a means of population control. It is from this time that medical and social acceptance of abortion can be dated, although previously the subject had not been discussed in public in modern times. It is suggested that it was largely due to de Sade's writing that induced abortion received the impetus which resulted in its subsequent spread in western society.
\end{abstract}

\section{Introduction}

Although the induction of abortion has been practised for over two millenia there have always been two distinct sets of criteria employed - those related to clinical urgency, and those of sociopolitical origin. Possibly the first recorded reference to abortion as a means of population control was the recommendation of Aristotle (384-322 BC) in his Politics that it be used to maintain the 'ideal' size of a city state wherever couples already had sufficient children. ${ }^{1}$ Aristotle claimed that the embryo did not possess life until 'quickening' and that abortion was, therefore, permissible prior to that time: in his History of Animals he computed this as the first 40 days of gestation for a male child, and the first 80 days for a female child. ${ }^{2}$

Three hundred years later early Christian thought rejected the concept of abortion. As early as the Ist century AD The Epistle of Barnabas stated 'Thou shalt not procure abortion, nor commit infanticide'. ${ }^{3}$ Sterilisation, contraception, and abortion at all stages of gestation were expressly forbidden by Pope Gregory IX (1227-124I) in the canon Si aliquis $^{4}$ and, despite subsequent differences of opinion over detail, ${ }^{5}$ this has remained essentially the view of the church of Rome to the present day.

In countries such as France, where the Roman Catholic church held sway until the close of the 18 th century, induced abortion, being a procedure specifically forbidden by the church, was simply not recognised by the medical profession as a therapeutic procedure. Indeed, apart from the mediaeval Latin translations of the roth century Canon of Avicenna (which was not displaced as the principal text book in western medical schools until about the middle of the I 7 th century) no reference to induced abortion appeared in any medical writings until the latter part of the I8th century. The first such modern reference was by William Cooper, a Doctor of Medicine in London who in 1769 suggested the possibility of inducing abortion as an alternative to the (then dreaded) caesarian operation, in order to resolve undeliverable pregnancies in cases of pelvic disproportion. ${ }^{6}$

Cazeaux (1883) subsequently claimed that Cooper's question on the propriety of abortion 'was shortly afterward decided in the affirmative by most English practitioners'.? In fact, no such opinion appeared in print in Britain until $1856,{ }^{8}$ but in France itself approval came much sooner. In 1813 Fodéré referred approvingly to induced abortion for the resolution of clinical problems in obstetrics as did Marc in 1821, Velpeau in 1829, and Cazeaux in $1840,{ }^{\circ}$ and from that time onwards medical approval for abortion as a therapeutic measure was common in France. By the 1880 s the author of virtually every textbook on obstetrics and gynaecology in every western country wrote approvingly of the practice, and none spoke against it. ${ }^{10}$

The pressures of modern society for induced abortion upon socio-political grounds can also be traced to this period, and it appears probable that the case was first formulated in 1795 .

\section{The Marquis de Sade}

The 18th century, although largely a time of peace in the military sense, was a period of considerable intellectual ferment. In the field of religion rationalism and deism flourished, and from these beliefs it was but an easy step for philosophers to manage without even the Deists' 'God'. During this period the writings of Voltaire (1694-1778), Rousseau (1712-78), Diderot (1713-84) and others, were aimed (inter alia) at the destruction of a faith which Voltaire thought unworthy of man.

There grew a widespread impiety, and increasingly scurrilous attacks were made upon the Christian faith and all that it held sacred. The worldliness and laxity of many of the principal clerics of the Roman Catholic church in France offered little resistance to such attacks and, when revolution finally broke out, the Catholic church and the Christian faith were targets for the revolutionaries, alongside the political institutions of the 
State. Following the teachings of Voltaire and the philosophes, the revolution aimed at overturning the social and religious mores of the times, as well as the structure of society.

One arch-priest of the new libertinism was Donatien François Alphonse de Sade (the Marquis de Sade, 1740-1814), who held all life cheaply and who, for most of his adult life, was obsessively concerned with making attacks upon God and the Christian church. De Sade was born into a family of ancient nobility on 2 June I740. He became a republican and revolutionary however, and spent over a third of his life in prison - although not always for any cause other than the spite of his personal enemies. ${ }^{11}$ It was possibly de Sade who was responsible for inciting the mob to storm the Bastille on 14 July 1789 (where he was imprisoned until II days before the incident, having been transferred to an asylum just too soon to thus gain his freedom), and he was subsequently imprisoned (and under sentence of death, for the second time in his life) for 'moderatism' and for behaving too leniently towards his wife's parents when he was President of a revolutionary court and they faced possible trial as aristocrats.

It was in de Sade's La Philosophie dans le Boudoir, first published in 1795 (during the year after his release from prison upon this latter occasion, and his narrow escape from the guillotine) that his remarks on abortion were made - the first open reference to the topic in modern times. $\mathrm{La}$ Philosophie is the shortest of de Sade's many works, and was possibly written with the simple aim of making money at a time when de Sade was destitute. About a third of the book was taken up by a roopage long pamphlet entitled Frenchmen, a further effort if you wish to be Republicans!; this was later reprinted separately (and anonymously) in 1848 as propaganda for the Paris Commune.

La Philosophie dans le Boudoir ${ }^{12}$ is notable for the violence of its attacks upon established religion, morality, family ties and social structures, and for its advocacy of sodomy, incest, lust and cruelty for their own sakes. Even in the permissive climate of society today this book must rank as exceptionally obscene and pornographic, and it has never been and still is not - on sale in Britain in any edition. Only three translations into English have ever been made; one of these ${ }^{18}$ has (very recently) appeared in the British Library's catalogue, one is now out of print, ${ }^{14}$ and neither of these, nor the other version ${ }^{15}$ has ever been sold in Britain. Study of this work has been extremely difficult, therefore, and the present comments are based upon a modern French reprint, ${ }^{16}$ and it is to this edition that the page numbers quoted below refer.

It can be argued that the pornographic content of La Philosophie is less important, in terms of potential effect upon its readers, than the lengthy philosophical monologues in which de Sade incorporated his views on morality. It was de Sade's belief thas as destructiveness is one of nature's first laws, destroy can never be a crime - and as murder is $n \overrightarrow{\vec{\theta}}$. more than a form of destruction it is thus to be approved:17 it followed that abortion is no le acceptable.

A large part of de Sade's thesis was concerneg with equality of the sexes, and as a practic procedure of value in the life of the sexualf liberated woman, he cited abortion as one of the ways by which she may avoid the punishment which society imposed for adultery. To avoid discovery the adultress must avoid pregnancy or, if that failed, have an abortion. ${ }^{18}$

The very fact of procreation was held in horro and, through the character of his 'heroine', Mme St-Ange, de Sade offered express advice to a womin who becomes pregnant. 'Don't be afraid of infant:cide; it is imagination to regard this as a crime; we are always mistresses of that which we carry in out bosom, and there is nothing wrong in destroying this sort of thing in the same way that one removôs others, by using medicines when we feel the need' This principle even applied when the child was at term: the right to abort a fetus was unarguable, such an action was seen by de Sade as part of nature.

De Sade continued by blaming upon religio what he referred to as 'mistaken' views concerning pregnancy. He scorned the view that man is not responsible for his own existence and that it is God who grants an embryo its soul: it was because 8 such 'gross errors' of belief (he said) that abortion was commonly considered a crime. ${ }^{19}$ The realist view, according to de Sade, was that as murder $\overline{\text { TS }}$ such a trivial matter then destruction of an infant; which has not achieved 'the age of reason', is ondy of 'small consequence'. ${ }^{19}$ Such practices, he said, are found throughout history amongst all peoples of the world, and this demonstrates the stupidity af regarding such a 'very unimportant action' as wrong. ${ }^{19}$

The lessons of history were referred to at lengt to support de Sade's contention that abortion and infanticide are natural behaviour. The customs of Madagascar, Greece, Rome and China were especially quoted with, not surprisingly, Aristotle support for abortion being singled out for specia mention. ${ }^{20}$

A further reason given for supporting bo abortion and infanticide in a republic was in orde that the population should not become too numerous - the converse of the situation in a monarchy, where large numbers of serfs were necessary. ${ }^{20}$ Too mang people were seen as merely parasites within $:$ republican State - extra mouths to feed - an especially did de Sade consider this to be so in has own country at the time he was writing. ${ }^{21}$ De Sade was very concerned with the concept of optimum population size, and would undoubtedly have

(1)


approved of the conclusions reached by Malthus three years later in his Essay on the Principle of Population. ${ }^{22}$

In the light of all these views, for de Sade the solution was simple. 'Do not put up with these disgraceful fruits of ones debauchery. One disposes of these hideous consequences in the same way as the results of one's digestion'. ${ }^{23}$ Thus de Sade regarded abortion as a mere triviality, analogous to purging unwanted matter from the intestines.

It is interesting to note that at various points in his essay de Sade produced most of the arguments in favour of induced abortion which have been used since then to advocate it for other than clinical reasons - population control; avoidance of a socially inconvenient pregnancy; disbelief in the fetus being a living human being; and the attitude that a fetus, being merely part of a woman's body, was hers to retain or destroy as she pleased.

De Sade's exhortations were in tune with the anti-religious (and anti-clerical) atmosphere in France during the age of revolution; his books sold well and undoubtedly played their part in establishing the new morality - or some might call it amorality - of the post-revolutionary period. It is certainly true that it was from this time onwards that the old prohibitions of the Roman Catholic church were increasingly disregarded by the medical profession. There was a strong anti-clericalism in post-revolutionary France which would not oppose any practice which the church had forbidden.

\section{Discussion}

Clinically, to the French medical profession of the early 19th century the logic of inducing abortion in early pregnancy in women known to have a malformed pelvis was inescapable. In such cases the only alternative was to allow the pregnancy to proceed and terminate it either by a caesarian operation or by embryotomy. Both of these procedures were seen at the time to carry a greater maternal mortality than did induced abortion. ${ }^{24}$ Taken into account with the newfound disregard for fetal life, such as had been expressed so openly by de Sade, the logical conclusion was that induced abortion was the preferred course whenever early diagnosis of pelvic disproportion could be made. The dis-approbation of the Roman Catholic church no longer acted as a deterrent for most French medical practitioners; and whether for clinical, for social, or for purely Malthusian reasons, abortion became so widespread in France during the I9th century that very real fears began to be felt for the maintenance of an adequate population size. ${ }^{25}$

Writing just over a century after the publication of La Philosophie Doléris, a Parisian accoucheur, commented upon the considerable increase in illegal abortions to be seen in the city's maternity hospitals. ${ }^{26}$ While many other factors had undoubtedly arisen in the intervening period to affect the incidence of induced abortion, it is significant that Doléris, one of the first to comment upon the open spread of abortion induced for other than clinical reasons, attributed this increase primarily to the spread of Malthusian and neo-Malthusian ideas on population control in a community predisposed by 'a sort of ultra-free education, which has spread amongst several social classes by means of novels, the theatre, meetings, etc., on subjects which previously had no writer or speaker prepared to put them before the general public' ${ }^{27}$ This is precisely the role which had been undertaken by de Sade at the time of the revolution; and it is from that time that the open appearance of induced abortion in western Europe dates.

It is surely not too fanciful to see in the Marquis de Sade the spiritual progenitor of the widespread use of induced abortion not only for clinical, but even more for social, economic, and political purposes, which is so evident today.

\section{References and notes}

${ }^{1}$ Aristotle, Politics, 7.16. $1335^{\mathrm{b}}$.

${ }^{2}$ Aristotle, Historia animalium, Bk VIII, Ch III, ss 3.4 Ch IV, s5.

${ }^{3}$ Lake, K (1952) (Transl.) The Epistle of Barnabas in The apostolic fathers xix 5, 402-3. London, Heinemann. The prohibition also occurs (in the same words) in the Didache (clst-4th century), ibid 31013, and the same concept was expressed by Tertullian in his Apologia (c200 AD), Glover, T R, (I93I) (Transl.) 48-9. London, Heinemann.

${ }^{4}$ Gregory IX (1682). Decretales Corpus iuris canonici 5.12.5. Basle.

${ }^{5}$ Farr, A D (1977). The valuation of fetal life. In Medical developments and religious belief. $\mathrm{PhD}$ Thesis, 327-31. Open University.

${ }^{6}$ Cooper, W (1772). A case of the caesarian section. Medical observations inquiries, 4, 26I-27I.

${ }^{7}$ Cazeaux, P (1883). Traité théoretique et pratique de l'art des accouchements, Ioth edition, 1067, Paris Lauwereyns.

${ }^{8}$ Clay, C (I856). Complete handbook of obstetric surgery. London, Renshaw. See also Farr, A D (op cit) 298-9.

${ }^{9}$ Cazeaux, $\mathrm{P}$, op cit.

${ }^{10}$ Farr, A D, op cit.

${ }^{11}$ Gorer, G (1934). The revolutionary ideas of the Marquis de Sade. London, Wishart.

${ }^{12}$ de Sade, D A F (1795). La philosophie dans le boudoir. Paris: Reprinted I970, Paris, Pauvert.

${ }^{13}$ Seaver, $\mathrm{R}$ and Wainhouse, A (1965) (Transl.) The complete fustine, philosophy in the bedroom and other writings, New York, Grove.

${ }^{14}$ Casavini, P (I953) (Transl.) The bedroom philosophies. Paris, Olympia.

${ }^{15}$ Gilette, P J (1966) (Ed. \& Transl.), The complete Marquis de Sade, 2 Vols, Los Angeles. Holloway House.

${ }^{16}$ de Sade, D A F, op cit.

${ }^{17}$ Ibid, p 97. 
18Ibid, pp 76-7.

${ }^{10}$ Ibid, p II5-18.

20Ibid, pp 266-68.

21 Ibid, p 59a.

${ }^{22}$ Malthus, T $\mathrm{R}$ (1798). An essay on the principle of population. London, Johnson.

${ }^{23}$ De Sade, D A F, op cit, p 59b.

${ }^{24}$ For the mortality rate of the caesarian operation in Europe in the period 1750-1839 see Kayser, C, (184I). De eventu sectionis caesaria 99 Copenhagen,
MD Thesis. For 19th century French views of the relative risks to the mother of embryotom? and induced abortion see Cazeaux, $P,(1851-2)$ in Bulletin de l'Académie Nationale Médecine, 1 . 389-90, Paris, Bailliere.

${ }^{25}$ Pouthas, $\mathrm{CH}$ (1956). La population francaise pendant $l$ premiere moitié du $\mathrm{Ig}^{e}$ siecles. $2 \mathrm{I}^{s}$. Paris.

${ }^{26}$ Doleris, J M (I905). Statistique sur l'avortemen Comptes rendu de la Société d'Obstétrique de Gynécologie et de Paediatrie de Paris, 7, 62-75.

${ }^{27}$ Ibid, p 73 